\title{
Correlation between placenta accreta and history of cesarean section among Iraqi Pregnant Women: Retrospective study
}

\author{
Nour Ali Abdulla*, Hawraa Hussein Ghafel*
}

Maternal and Neonate Nursing Department, College of Nursing, University of Baghdad, Baghdad, Iraq.

*Correspondence to: Hawraa Hussein Ghafel (E-mail: hawraah@conursing.uobaghdad.edu.iq)

(Submitted: 24 January 2021 - Revised version received: 09 February 2021 - Accepted:08 March 2021 - Published online: 26 April 2021)

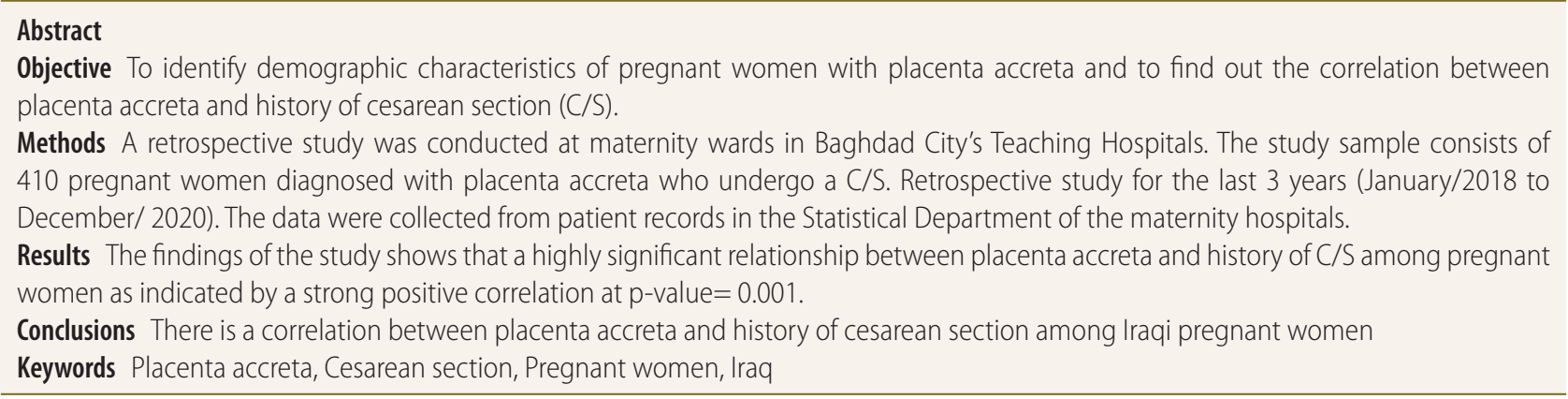

\section{Introduction}

Placenta accreta is a potentially life-threatening complication of pregnancy characterized by implantation that occurs when placental trophoblasts invade into the uterine wall. ${ }^{1}$ Placenta accreta precise pathogenesis is unknown. A suggested hypothesis involves low deciduous development, excessive invasion of trophoblastic, or a combination of both. ${ }^{2}$ Based on the depth of attachment and invasion into the muscular layers of the uterus, three grades of irregular placental attachment are defined: Accreta - chorionic villi, rather than being confined within the decidua basalis, are connected to the myometrium, Increta: invade chorionic villi into the myometrium, Percreta: chorionic villi enter via the perimetrium (uterine serosa). Placenta accreta is associated with an elevated risk of excessive bleeding at the time of attempted vaginal delivery due to irregular attachment to the myometrium. There is a constant need for blood supplies to be transfused, and surgical uterine removal (hysterectomy) is often important to control life-threatening bleeding. ${ }^{3,4}$ Previous cesarean delivery, uterine instrumentation, and intrauterine scarring are risk factors for placenta accreta, both of which can be associated with disruption or absence of decidua basalis, as well as placenta previa, obesity, maternal age over 35, grand multiparty, and persistent miscarriage. ${ }^{56}$

\section{Methodology}

A retrospective study among pregnant women diagnosed with placenta accreta who undergo a cesarean section $(\mathrm{C} / \mathrm{S})$ at maternity wards in Baghdad City's Teaching Hospitals. A non-probability purposive sample consists of 410 pregnant women. The data were collected from patient records in the Statistical Department of the maternity hospitals, for the last 3 years (January/2018 to December/2020). This questionnaire was composed of three parts, part1: sociodemographic characteristics include: Age, level of education of the mother, women's occupation, blood groups, monthly income, smoking, BMI, Rh factor, and residency. Part 2: Obstetrical and Past Medical History includes: Gravidity, parity, abortion, gestational age, mode of the previous delivery, gestational age in weeks (a pregnancy with which placenta accreta occurred, interval between the last $\mathrm{C} / \mathrm{S}$ and the current pregnancy. Anemia, heart disease, hypertension, diabetes, goiter, viral hepatitis, food allergy, drugs allergy, and do not suffer from diseases. Part 3: Placental complications and risk factors for placenta accreta.

\section{Results}

Table 1 shows that pregnant women are with age $32 \pm 6$ years in which $50.7 \%$ of them is with age $30-39$ years and $30.3 \%$ are with age group 20-29 years. The blood group presents that $46.1 \%$ of pregnant women are of blood group "O", $23.1 \%$ of them are of "AB" group, $19.3 \%$ are of "B" blood group, and only $11.5 \%$ are of "A" blood group. The Rh factors refers that $76.6 \%$ of pregnant women are with positive Rh factors while $23.4 \%$ are with negative factor. Regarding occupation, $71.2 \%$ of pregnant women are housewives and only $22.4 \%$ are governmental employee. The residency variable shows that $65.4 \%$ of pregnant women residents at urban area and $21.5 \%$ are resident at suburban area. The smoking status shows that $88.5 \%$ of pregnant women are not smoking and only $11.5 \%$ of them are smoking.

Table 2 reveals that pregnant women having history of 5-7 gravidity (43.4\%) in which average refers to $6 \pm 2$ pregnancies. The table shows that $45.4 \%$ of pregnant women having history of 1-3 lived children and 38\% having 4-6 lived child. All of pregnant women were getting $\mathrm{C} / \mathrm{S}$ as a mode of delivery (100\%), $45.9 \%$ of them are having $4-6 \mathrm{C} / \mathrm{S}$ and $32.4 \%$ are having 1-3. More than half of pregnant women show they have no abortion but $25.6 \%$ of them have one abortion previously. The gestational age by ultrasound at birth among pregnant women refer to third semester among most of them (99\%). The gestational age by ultrasound at birth refers to 28-32 weeks among most of the pregnant women (99\%). The interval between last $\mathrm{C} / \mathrm{S}$ and current pregnancy refers to 2 years among the highest percentage of pregnant women $(37.8 \%)$.

This table depicts that there is high significant relationship between placenta accreta and history of $\mathrm{C} / \mathrm{S}$ among 


\begin{tabular}{|c|c|c|c|c|}
\hline List & Chara & istics & $f$ & $\%$ \\
\hline \multirow[t]{5}{*}{1} & \multirow{5}{*}{$\begin{array}{l}\text { Age } \\
(M \pm S D=32 \pm 6)\end{array}$} & $\leq 19$ years & 11 & 2.7 \\
\hline & & 20-29 year & 124 & 30.3 \\
\hline & & 30-39 year & 208 & 50.7 \\
\hline & & $40 \leq$ year & 67 & 16.3 \\
\hline & & Total & 410 & 100 \\
\hline \multirow[t]{5}{*}{2} & Blood group & A & 47 & 11.5 \\
\hline & & B & 79 & 19.3 \\
\hline & & 0 & 189 & 46.1 \\
\hline & & $A B$ & 95 & 23.2 \\
\hline & & Total & 410 & 100 \\
\hline \multirow[t]{3}{*}{3} & Rh factor & Positive & 96 & 23.4 \\
\hline & & Negative & 314 & 76.6 \\
\hline & & Total & 410 & 100 \\
\hline \multirow[t]{5}{*}{4} & Occupation & Housewife & 292 & 71.2 \\
\hline & & Employee & 92 & 22.4 \\
\hline & & Retired & 2 & 0.5 \\
\hline & & Student & 24 & 5.9 \\
\hline & & Total & 410 & 100 \\
\hline \multirow[t]{4}{*}{5} & Residency & Urban & 268 & 65.4 \\
\hline & & Rural & 54 & 13.2 \\
\hline & & Suburban & 88 & 21.5 \\
\hline & & Total & 410 & 100 \\
\hline \multirow[t]{3}{*}{6} & Smoking & No & 363 & 88.5 \\
\hline & & Yes & 47 & 11.5 \\
\hline & & Total & 410 & 100 \\
\hline
\end{tabular}

f: Frequency, \%: Percentage, M: Mean, SD: Standard deviation.

pregnant women as indicated by strong positive correlation at $\mathrm{p}$-value $=0.001$.

\section{Discussion}

The result in the Table 1 shows that the highest percentage of pregnant women with placenta accreta is $50.7 \%$ among the age group 30-39 years. Also, the present study found a high significant relationship among age and incidence of placenta accreta at $\mathrm{p}$-value $=0.001$. The results show that the highest percentage of pregnant women (46.1\%) of their blood group is "O", and this result is consistent with that obtained with Salman et al. ${ }^{7}$ who found it was $56 \%$ with blood group $(\mathrm{O})$ and this could be due to race and genetic. The majority of the sample (71.2\%) were housewives, and $22.4 \%$ of them are governmental employees. The women's occupation have a role in increasing placenta accreta during pregnancy especially exhaustion work and may have an effect on her pregnancy and may lead to antepartum hemorrhage, low birth weight, and preterm labor. Regarding residency, the highest percentage (65.4\%) of the study sample
Table 2. Distribution of pregnant women according to their obstetrical history.

\begin{tabular}{|c|c|c|c|c|}
\hline List & \multicolumn{2}{|c|}{ History } & $f$ & $\%$ \\
\hline \multirow[t]{5}{*}{1} & \multirow{5}{*}{$\begin{array}{l}\text { Gravid a } \\
(M \pm S D=6 \pm 2)\end{array}$} & $2-4$ & 143 & 34.9 \\
\hline & & $5-7$ & 178 & 43.4 \\
\hline & & $8-10$ & 74 & 18 \\
\hline & & $11 \leq$ & 15 & 3.7 \\
\hline & & Total & 410 & 100 \\
\hline \multirow[t]{6}{*}{2} & \multirow{6}{*}{$\begin{array}{l}\text { Para } \\
(\mathrm{M} \pm \mathrm{SD}=4 \pm 2)\end{array}$} & None & 3 & 0.7 \\
\hline & & $1-3$ & 186 & 45.4 \\
\hline & & $4-6$ & 156 & 38 \\
\hline & & $7-9$ & 52 & 12.7 \\
\hline & & $10 \leq$ & 13 & 3.2 \\
\hline & & Total & 410 & 100 \\
\hline \multirow[t]{3}{*}{3} & \multirow{3}{*}{$\begin{array}{l}\text { Mode of previous } \\
\text { delivery }\end{array}$} & Normal delivery & 0 & 0 \\
\hline & & Cesarean section & 410 & 100 \\
\hline & & Total & 410 & 100 \\
\hline \multirow[t]{5}{*}{4} & \multirow{5}{*}{$\begin{array}{l}\text { Number of } \\
\text { previous delivery }\end{array}$} & $1-3$ & 133 & 32.4 \\
\hline & & $4-6$ & 188 & 45.9 \\
\hline & & $7-9$ & 67 & 16.3 \\
\hline & & $10-12$ & 22 & 5.4 \\
\hline & & Total & 410 & 100 \\
\hline \multirow[t]{6}{*}{5} & \multirow{6}{*}{$\begin{array}{l}\text { Number of } \\
\text { abortion }\end{array}$} & None & 223 & 54.4 \\
\hline & & 1 & 105 & 25.6 \\
\hline & & 2 & 45 & 11 \\
\hline & & 3 & 27 & 6.6 \\
\hline & & $4+$ & 10 & 2.4 \\
\hline & & Total & 410 & 100 \\
\hline \multirow[t]{4}{*}{6} & \multirow{4}{*}{$\begin{array}{l}\text { Pregnancy } \\
\text { trimester } \\
\text { (pregnancy with } \\
\text { placenta accrete) }\end{array}$} & First semester & 0 & 0 \\
\hline & & Second semester & 4 & 1 \\
\hline & & Third semester & 406 & 99 \\
\hline & & Total & 410 & 410 \\
\hline \multirow[t]{4}{*}{7} & \multirow{4}{*}{$\begin{array}{l}\text { Gestational age } \\
\text { by ultrasound at } \\
\text { birth }\end{array}$} & $1-12$ week & 0 & 0 \\
\hline & & 13 - 27 week & 4 & 1 \\
\hline & & 28 - 38 week & 406 & 99 \\
\hline & & Total & 410 & 100 \\
\hline \multirow[t]{6}{*}{8} & \multirow{6}{*}{$\begin{array}{l}\text { Time between } \\
\text { last cesarean } \\
\text { and current } \\
\text { pregnancy } \\
(\mathrm{M} \pm \mathrm{SD}=2 \pm 1)\end{array}$} & None & 1 & 0.2 \\
\hline & & 1 years & 81 & 19.8 \\
\hline & & 2 years & 155 & 37.8 \\
\hline & & 3 years & 96 & 23.4 \\
\hline & & $4+$ years & 77 & 18.8 \\
\hline & & Total & 410 & 100 \\
\hline
\end{tabular}

f: Frequency, \%: Percentage. 
Table 3. Correlation between placenta accreta and history of cesarean section among Iraqi pregnant women $(\mathrm{N}=80)$.

\begin{tabular}{llcc}
\hline Correlation & & $\begin{array}{c}\text { Placenta } \\
\text { accreta }\end{array}$ & $\begin{array}{c}\text { Cesarean } \\
\text { section }\end{array}$ \\
\hline $\begin{array}{l}\text { Placenta } \\
\text { accreta }\end{array}$ & Pearson Correlation & 1.00 & $0.216^{* *}$ \\
$\begin{array}{l}\text { Cesarean } \\
\text { section }\end{array}$ & pearson Correlation & -- & 0.001 \\
& p-value & $0.216^{* *}$ & 1.00 \\
\hline
\end{tabular}

${ }^{*}$ Correlation is significant at the 0.01 level (2-tailed).

were living in an urban area. This result does not agree with Salman et $\mathrm{al}^{7}$ who found the pregnant women with placenta accreta live in rural areas (60\%). Women who live in rural have low awareness and low commitment about prenatal visits and have poor education about signs and symptoms of accreta.

The result shows that the majority of the sample (88.5\%) of pregnant women is not smoker but there is a highly significant relationship between smoking and placenta accreta at $\mathrm{p}$-value $=$ 0.001. Smoking is a biologically plausible risk factor in contribution to compensatory placenta hypertrophy. Table 2 indicates that result the highest percentage (43.4\%) of study sample were multigravida $^{5-7}$ pregnancies, there is a significant relationship between gravidity and placenta acreta at $p$-value $=0.025$. The lack of health education about family planning and the number of gravidity, and refusing use of family planning methods (especially in rural areas) lead to increased number unplanned pregnancy. Regarding mode of previous delivery, the highest percentage $(100 \%)$ of the study sample were had a previous history of $\mathrm{C} / \mathrm{S}$. This result agreed with AbdElfatah et $\mathrm{al}^{8}$ who found that $100 \%$ of pregnant women were getting $\mathrm{C} / \mathrm{S}$ as a mode of delivery. Most of pregnant women undergo cesarean delivery because of their fear of natural childbirth pain, they believe the cesarean delivery is less painful than a normal birth. Regarding of the number of previous delivery, $45.9 \%$ of them have $4-6$ multiparty and $32.4 \%$ of them is having $1-3$ cesarean delivery. These results show that there is a significant association between the number of $\mathrm{C} / \mathrm{S}$ and incidence of placenta accreta.

The result indicates that $54.4 \%$ of the study sample did not have abortion, while $25.6 \%$ of them had one previous abortion.
Sofiah and Fung ${ }^{9}$ who said that a number of previous curettage increase the incidence of placenta accreta.

The highest percentage of the study sample (99\%) were in 28-40 weeks of gestational age (pregnancy with placenta accreta). This result refers to most of pregnant women with placenta accrete at the third trimester of their pregnancy. Mohamed and Ahmed ${ }^{10}$ found that the gestational age more than 30 weeks of women with placenta accreta. The majority of patients with placenta accreta was diagnosed with placenta accreta at the moment of birth in Iraqi, there is no previous diagnosis during prenatal visits.

Regarding the detecting of gestational age by using of ultrasound at among pregnant women refers to most of pregnant women with placenta accreta were diagnosed at third semester (99\%). Placenta accreta is detected at the moment of birth and not during prenatal visits in Iraq because most of women were not committed in prenatal visits. The results indicate the interval between the last $\mathrm{C} / \mathrm{S}$ and current pregnancy is 2 years, the highest percentage of pregnant women $(37.8 \%)$ have 2 years interval between one delivery and another. Women's need to increase their awareness about family planning for regulating the intervals between pregnancies to avoid incidence and complications of placenta accreta.

Table 3 shows that there is a highly significant relationship between placenta accreta and history of $\mathrm{C} / \mathrm{S}$ among pregnant women as indicated by a strong positive correlation at $\mathrm{p}$-value $=$ 0.001 . Fitzpatrick et $\mathrm{al}^{11}$ who found a relationship between placenta accreta and history of C/S. Performing repeated cesarean deliveries increases the chances of placenta accreta due to a wound in the uterine muscle in every $\mathrm{C} / \mathrm{S}$, causing abnormality in the area of placenta implantation and preventing it from attaching normally and causing its implantation into the uterine muscle rather than implant in to the myometrium.

\section{Conclusion}

There is a correlation between placenta accreta and the history of $\mathrm{C} / \mathrm{S}$ among pregnant women.

\section{Conflict of Interest}

None.

\section{References}

1. Eshkoli, T, Weintraub, AY, Sergienko, R, Sheiner, E. Placenta accreta: risk factors, perinatal outcomes, and consequences for subsequent births. Am J Obstet Gynecol, 2013;208(3):219-e1.

2. Garmi, G, Goldman, S, Shalev, E, Salim, R. The effects of decidual injury on the invasion potential of trophoblastic cells. Obstet Gynecol, 2011;117(1):55-59.

3. Smith, ZL, Sehgal, SS, Van Arsdalen, KN, Goldstein, IS. Placenta percreta with invasion into the urinary bladder. Urol Case Rep, 2014;2(1):31-32.

4. Cahill, AG, Beigi, R, Heine, RP, Silver, RM, Wax, JR, Gynecologists, AC of O. Placenta accreta spectrum. Am J Obst Gynecol, 2018;219(6):B2-B16.

5. Gielchinsky, Y, Rojansky, N, Fasouliotis, SJ, Ezra, Y. Placenta accretasummary of 10 years: a survey of 310 cases. Placenta, 2002;23(2-3): 210-214.

6. Practice, C. on O. ACOG committee opinion. Placenta accreta. Number 266, January 2002. American College of Obstetricians and Gynecologists. Int J Gynaecol Obstet Off Organ Int Feder Gynaecol Obstet, 2002:77(1):77.

7. Salman, ST, Mohammed, AH, Noaman, NG, Ibrahim, HK. Prevalence of placenta accreta in Diyala governorate during 2010-2012 years. Med J Tikrit, 2013;19(2):286-295

8. AbdElfatah, EA, Awad, EEM, Abd-Eldaym, TM, Ali, ZH. Outcome of patients with placenta accreta at El Shatby Maternity University Hospital. Open J Obstet Gynecol, 2017;7(7):725.

9. Sofiah, S, Fung, YC. Placenta accreta: clinical risk factors, accuracy of antenatal diagnosis and effect on pregnancy outcome. Med J Malay, 2009:64(4):298-302.

10. Mohamed, AH, Ahmed, IMM. Incidence of placenta accreta and its complications in cases of previous cesearean sections with placenta previa anterior at Al Hussein University Hospital. Egypt J Hosp Med, 2018;73(3):6310-6315.

11. Fitzpatrick, KE, Sellers, S, Spark, P, Kurinczuk, JJ, Brocklehurst, P, Knight, M Incidence and risk factors for placenta accreta/increta/percreta in the UK: a national case-control study. PLoS One, 2012:7(12):e52893. 